\title{
Trust and livelihood adaptation: evidence from rural Mexico
}

\author{
Sytske F. Groenewald • Erwin Bulte
}

Accepted: 4 April 2012/Published online: 23 June 2012

(C) The Author(s) 2012. This article is published with open access at Springerlink.com

\begin{abstract}
This paper explores the relationship between trust and household adaptation strategies for a sample of respondents in a Mexican agrarian community. In particular, we analyze how levels of personalized, generalized, and institutionalized trust shape the adaptation strategies of smallholders, and find that households characterized by low levels of generalized and institutionalized trust are less likely to be involved in a diversified livelihood strategy. Instead, they tend to continue with the traditional activity of maize production. In contrast, high levels of personalized trust are associated with a livelihood strategy that focuses on cattle breeding and pasture growing. We argue that trust explains why some people more readily 'catch up' with opportunities created by an expanding market, while others lag behind in poverty. This paper thus seeks to contribute to the debate on the role of trust in economic actions and decision-making processes of smallholders.
\end{abstract}

Keywords Rural livelihoods - Adaptation . Smallholders · Market liberalization · Trust . Social capital $\cdot$ Mexico

Abbreviations
$\begin{array}{ll}\text { IV } & \text { Instrumental variable } \\ \text { KMO } & \text { Kaiser-Meyer-Olkin } \\ \text { PCA } & \text { Principal component analysis }\end{array}$

S. F. Groenewald $(\square)$

Sociology of Consumers and Households, Wageningen University, Postbus 8060, 6700 DA Wageningen, The Netherlands

e-mail: groenewald@hotmail.com

E. Bulte

Development Economics Group, Wageningen University, Postbus 8060, 6700 DA Wageningen, The Netherlands

e-mail: Erwin.bulte@wur.nl

\section{Introduction}

Since the 1980s, the Mexican government has embraced market liberalization and implemented neoliberal policy reforms to stabilize the economy, stimulate efficiency gains and sustainable economic growth, and alleviate rural poverty. Subsequently, the Mexican agricultural sector has undergone substantial reforms with far-going consequences for the livelihoods of smallholders. Local smallholders are forced to adapt to economic pressures caused by lower prices for maize and other traditional crops, weak local and regional demands, and large reductions in public sector support for agriculture (Wise 2007). While there is a growing interest in identifying smallholders' individual adaptation strategies and measuring their impact on poverty, little attention is directed at explaining the factors that shape their choices for a certain adaptation strategy (Pelling and High 2005).

Smallholders' adaptation to global change is a dynamic process of long-term shifts in household strategies in response to actual or expected effects of contextual change (Smit and Wandel 2006). These strategies can enhance existing security and wealth, or reduce vulnerability (Davies and Hossain 2007). Adaptation can be reactive, concurrent, or anticipatory, spontaneous, or planned (Pelling and High 2005) in response to changing conditions, stress, hazard, risk, or opportunities in the environment (Smit and Wandel 2006). The social-economic environment is important because it determines people's access to resources, and therefore options and capacity to adapt. However, most adaptation studies have a narrow focus on individual rational choice, and ignore the wider structural context in which decision-making takes place (Pennartz and Niehof 1999; Murray 2001). Consequently, little is known about the significance of macro-economic changes for rural 
livelihoods, and why some groups of actors are able to take up opportunities generated by an expanding economy, while others are not (Bussolo and Lecomte 1999).

This paper examines how trust influences adaptive behavior of smallholders and affects economic outcomes. We use surveys to obtain various measures of trust, and use factor analysis to identify underlying factors (allowing us to distinguish between institutionalized, personalized, and generalized trust). We then relate our trust proxies to adaptation strategies and wealth levels. We thus connect the notions of adaptation and trust (related to social capital) to obtain a better understanding of the social factors that influence households' adaptation choices. Specifically, we ask which trust dimensions matter for adaptation behavior and livelihood choices, and ask how trust variables (via livelihood choices) matter for the accumulation of assets.

Since mid-1980, an increasing number of studies attribute economic differences between groups of actors to differential levels of social capital in addition to standard economic variables. While social capital is an elusive concept in social sciences, most studies agree it consists of three important dimensions: trust, social norms, and membership of social networks (see, e.g.,Putnam 1995; Durlauf and Fafchamps 2004; Portes 1998). We focus on the role of trust in adaptation strategies. Trust may be considered an asset for economic activities, as it promotes cooperation and stimulates more efficient social and economic exchange (Dasgupta 1998). As stated by Arrow (1972, p. 357), "virtually every commercial transaction has within itself an element of trust, certainly any transaction conducted over a period of time. It can be plausibly argued that much of the economic backwardness in the world can be explained by the lack of mutual confidence." Economists have used cross-country studies to demonstrate a positive correlation between trust indicators and macro-level economic performance (Fukuyama 1995; Knack 2000; Zak and Knack 2001; Tabillini 2007; Knack and Keefer 1997; La Porta et al. 1997). Similarly, Easterly (2005) argues that top-down market reform and liberalization in the 1980s and 1990s in many developing countries failed to yield the desired results due to the absence of sufficient 'trust'. In addition, Uslaner (2002) argued social trust causes positive economic outcomes such as volunteering, charity, and advocacy for policies promoting growth.

Few studies pay attention to the factors that determine the relationship between trust and economic outcomes. We use the livelihood framework to unravel this relationship at the household level. We seek to 'unpack' total household income and analyze the role of trust in adaptation strategy choice. Based on earlier studies we assume that current levels of trust are shaped by experiences. Consequently, we use qualitative data on recent historical events in the social and institutional context to explain contemporary characteristics of trust. This case study is contextualized by the specificity of Mexico's transition from state-directed rural development to neoliberal-guided rural development in the 1990s.

This paper aims to contribute to a more comprehensive understanding of the historical 'embeddedness' of trust building that ultimately shapes adaptive choices and actions. We provide evidence that households' capacity to adapt to market opportunities is shaped by local trust indicators, and argue that livelihood adaptation should be understood within larger and encompassing processes going on within the society at large.

\section{Livelihoods and social capital}

We use the livelihoods framework to analyze how neoliberal reforms alter the opportunities and constraints of smallholder livelihoods and shape household adaptation capacity. A commonly used definition of 'livelihood' is provided by Ellis (2000, p. 10): "the assets (natural, physical, human, financial and social capital), the activities, and the access to these (mediated by institutions and social relations) that together determine the living gained by an individual or household."

People use assets to respond to risks, uncertainties, and opportunities, balancing security and income objectives. Adaptation strategies are ex ante household strategic decisions anticipating failures in income streams due to changing circumstances within a relatively long-term perspective (Davies 1993). Coping strategies are medium-term ex post strategies in response to unanticipated failure in major resources necessary to make ends meet (Zoomers 1999). The adaptation capacity of small-holders is defined as the extent to which they can benefit from newly created opportunities, and are able to use these to reduce risk and vulnerability. We use the concept of social capital to analyze the intersection between social relations and purposive actions. Following Grootaert and Van Bastelaer (2002), we distinguish between two components of social capital: structural and cognitive social capital. Structure is derived from the various forms of organization that people are part of, particularly roles, rules, precedents, procedures, as well as a wide variety of networks that contribute to cooperation and collective action. The content of social capital consists of cognitive features, embedded in people and resulting from mental processes. It is manifested in trust, local ethics, traditions, morals, shared norms, attitudes, and beliefs (Uphoff 2000).

Trust and economic activity

The term trust is used in a variety of distinct, and sometimes incompatible ways (Kramer 1999). Trust may be seen as an optimistic expectation or belief regarding other 
agents' behavior and the social system in which they are embedded (Garfinkel 1963). It involves people's belief in others' intentions not to harm them, to respect their rights, and to carry out obligations (Sabatini 2009). In other words, trust refers to the confidence that a partner will not exploit the vulnerabilities of the other (Gambetta 1998). We follow Fukuyama (1995, p. 26) and consider trust "the expectation that arises within a community of regular, honest and cooperative behavior, based on commonly shared norms on the part of other members of that community." Knack and Keefer (1997) argue that trust and norms of civic cooperation are stronger in countries with formal institutions that protect property and contract rights, and in countries that are less polarized along lines of class or ethnicity. Similarly, Whiteley (2000) finds that social capital has a positive influence on growth that matches the influence of human capital (see also Zak and Knack 2001). Using cross-section data from 48 countries, Calderón et al. (2002) show that trust is correlated with financial depth and efficiency and with stock market development. Beugelsdijk et al. (2004) find that the marginal impact of trust on growth is greater in low-trust countries, and Ahlerup et al. (2009) show that the marginal effect of trust decreases with institutional strength. Social capital and formal institutions may be substitutes in development, so that social capital is especially important for the poorest countries where formal institutions are weak. However, Tu and Bulte (2010) find that trust and formal institutions may feed off each other as well. Greater trust results in greater market participation.

Broadly speaking, the literature defines three types of trust. The first is 'personalized trust', existing within established relationships and social networks (Hughes et al. 2000). The second is 'generalized trust' and comprises trust extended to strangers (Putnam 1998; Dasgupta 1998; Uslaner 1999). The third type of trust is 'institutionalized trust', which refers to basic confidence in the formal institutions of governance, including fairness of rules, official procedures, dispute resolution, markets and resource allocation, or the political, tax or juridical system (Stone 2001). The origin of these types of trust seems to vary. Personalized trust arises from repeated interactions (Fafchamps 2002), while generalized and institutionalized trust are not based on experience but arise respectively from actors' general knowledge about the population and the support they have received from the government and formal institutions (e.g., Knack and Keefer 1997; Platteau 1994). Moreover, generalized and institutionalized trust are transmitted within the family, from parents to children (cf. Algan and Cahuc 2006, 2007; Guiso et al. 2006; Dohmen et al. 2006). Tabillini (2007) argues that distant political institutions affect current trust attitudes and values with possible economic effects. Trust moves slowly and is influenced by political and economic outcomes in the past. This links up with the notion of agency and the idea that actors' contemporary choices oriented to future trajectories are informed by past experience (in its 'iterational' or habitual aspect) (Emirbayer and Mische 1994).

Based on this review, we expect that the local history influences contemporary trust levels, and accordingly shapes present adaptation choices and economic outcomes.

\section{Data and empirical strategy}

We used a combination of qualitative and quantitative approaches to analyze the multidimensional nature of household adaptation to market changes. The quantitative measurements of livelihood strategies are placed against a local social-historical and cultural background. To collect data, the first author conducted a field study of 12 months between March 2007 and May 2010. The qualitative research on smallholder livelihoods included participant observation, semi-structured interviews, case studies, and life histories with representatives of various groups of members of the local community. The qualitative data are primarily used to get insight into the socio-historical context. Valuable information was gathered through 30 in-depth interviews. Key informants were interviewed for their knowledge on specific issues. These interviews were used to get a better understanding of the social, cultural, economic, and historical context at the community level. Quantitative data on livelihood strategies and social capital were collected by means of a household survey among 200 households, comprising 848 persons, which is about $60 \%$ of the population in the study area. The survey included a section on the role of social networks and trust in livelihood activities.

The study was carried out in Morelos, a rural community that is part of the municipality Soteapan, located in the biosphere reserve Sierra de Santa Marta (Veracruz, Mexico). The villagers are indigenous Popoluca, for whom Spanish is a second language. Soteapan is one of the most deprived regions in the state, and among the most marginal in the country. In 2005, $75 \%$ of the population lived in extreme poverty, with incomes of less than US\$51.60 per month (Buckles and Erenstein 1996; CONEVAL 2005). Agriculture is the main livelihood activity, and local smallholders primarily cultivate maize. The local maize farming system is based on subsistence and commercial production, through which farmers interact with (local) maize markets. Maize production takes place under rainfed conditions and is entirely manual, due in part to the steep, rocky terrain. Nevertheless, in terms of total production, Morelos belongs to the top five municipalities out of 212 municipalities in Veracruz (INEGI 2005). 
Measuring trust, adaptation strategies, and wealth

We used (semi-structured) in-depth interviews to obtain a first impression of the characteristics and developments of trust and social relations among community members. In life histories, male and female respondents provided valuable information on historical events that affected levels of trust. Moreover, case studies provided a holistic understanding of contemporary dynamics related to social networks and trust. In addition, the household survey contained three sets of trust questions. These questions are summarized in Table 1 (part 1). The first set of questions aims to measure personalized trust, and the second and third set of questions seek to measure, respectively, generalized and institutionalized trust. The perceptions of respondents on trust statements were obtained using a 5-level Likert scale $(1=$ strongly disagree and $5=$ strongly agree).

Table 1 Summary statistics

\begin{tabular}{|c|c|c|c|c|c|c|}
\hline Variable & Description & Obs & Mean & SE & Min & Max \\
\hline Part 1 & Trust indicators & & & & & \\
\hline $\mathrm{T} 1$ & I trust my family/friends & 200 & 3.88 & 0.932 & 1 & 5 \\
\hline $\mathrm{T} 2$ & I trust my compadres & 200 & 3.355 & 1.060 & 1 & 5 \\
\hline $\mathrm{T} 3$ & I trust my neighbors & 200 & 3.04 & 1.084 & 1 & 5 \\
\hline $\mathrm{T} 4$ & I trust coyotes & 200 & 2.48 & 1.143 & 1 & 5 \\
\hline $\mathrm{T} 5$ & I trust leaders of farmer groups & 200 & 2.45 & 1.074 & 1 & 5 \\
\hline T6 & I trust other ejidatarios/farmers & 200 & 2.56 & 1.110 & 1 & 5 \\
\hline $\mathrm{T} 7$ & $\begin{array}{l}\text { In general, I trust most members } \\
\text { of the community }\end{array}$ & 200 & 2.655 & 1.101 & 1 & 5 \\
\hline $\mathrm{T} 8$ & $\begin{array}{l}\text { In general, community members have } \\
\text { a cooperative attitude }\end{array}$ & 200 & 2.685 & 1.180 & 1 & 5 \\
\hline T9 & $\begin{array}{l}\text { In general, community members are more } \\
\text { focused on own individual goals instead } \\
\text { of collective goals }\end{array}$ & 200 & 2.73 & 1.092 & 1 & 5 \\
\hline $\mathrm{T} 10$ & $\begin{array}{l}\text { In general, community members support } \\
\text { each other }\end{array}$ & 200 & 2.015 & 0.916 & 1 & 5 \\
\hline $\mathrm{T} 11$ & I trust the government and their policies & 200 & 2.72 & 1.187 & 1 & 5 \\
\hline $\mathrm{T} 12$ & The government treats everyone equal & 200 & 2.735 & 1.188 & 1 & 5 \\
\hline T13 & $\begin{array}{l}\text { People are poor because they are not given } \\
\text { the same changes as others }\end{array}$ & 200 & 2.655 & 1.049 & 1 & 5 \\
\hline T14 & I participate in community activities & 200 & 1.99 & 1.236 & 1 & 5 \\
\hline T15 & $\begin{array}{l}\text { In general, community members participate } \\
\text { in community activities }\end{array}$ & 200 & 1.703 & 0.566 & 1 & 5 \\
\hline \multirow[t]{9}{*}{ Part 2} & Land and labor allocation & & & & & \\
\hline & Farm self-employment & 200 & 83.866 & 25.689 & 0 & 100 \\
\hline & Farm labor employment & 200 & 5.121 & 14.454 & 0 & 80 \\
\hline & Non-farm self-employment & 200 & 4.826 & 13.657 & 0 & 90 \\
\hline & Non-farm labor employment & 200 & 5.686 & 17.041 & 0 & 95.2 \\
\hline & $\%$ agricultural time on crop & 200 & 3.85 & 9.819 & 0 & 80 \\
\hline & $\%$ agricultural time on maize & 200 & 94.8 & 13.865 & 10 & 100 \\
\hline & $\%$ land allocated to maize & 200 & 91.332 & 20.275 & 10 & 100 \\
\hline & $\%$ land allocated to crop & 200 & 8.668 & 20.275 & 0 & 90 \\
\hline Part 3 & Control variables & & & & & \\
\hline C. VAR1 & Land owned (ha.) & 200 & 4.4 & 6.758 & 0 & 27 \\
\hline C. VAR2 & Household size & 200 & 4.24 & 1.791 & 1 & 12 \\
\hline C. VAR3 & Sex household head (female $=1$ ) & 200 & 0.11 & 0.314 & 0 & 1 \\
\hline C. VAR4 & Age household head & 200 & 39.63 & 13.408 & 14 & 72 \\
\hline C.VAR5 & Household dependency ratio & 200 & 0.600 & 0.527 & 0 & 2.5 \\
\hline C. VAR6 & Illiteracy household head (yes $=1$ ) & 200 & 0.47 & 0.500 & 0 & 1 \\
\hline C. VAR7 & Urban land title (yes $=1)$ & 200 & 0.69 & 0.464 & 0 & 1 \\
\hline
\end{tabular}


Table 2 Rotated factor analysis trust indicators

\begin{tabular}{lllll}
\hline Variable & Factor 1 & Factor 2 & Factor 3 & Uniqueness \\
\hline T1 & & 0.737 & 0.416 \\
T2 & & 0.873 & 0.230 \\
T3 & & 0.837 & 0.290 \\
T4 & 0.650 & & & 0.487 \\
T5 & 0.315 & & & 0.365 \\
T6 & 0.437 & & & 0.399 \\
T7 & 0.779 & & & 0.342 \\
T8 & 0.832 & & & 0.303 \\
T9 & 0.715 & & & 0.460 \\
T10 & 0.505 & & & 0.628 \\
T11 & & 0.343 & & 0.635 \\
T12 & & 0.306 & & 0.300 \\
T13 & & 0.284 & & 0.465 \\
T14 & & 0.304 & & 0.695 \\
T15 & & 0.332 & & 0.758 \\
\hline
\end{tabular}

(Blanks abs(loading) $<0.25)$

Observations $=200 ; \chi^{2}(91)=1299.55 ;$ Prob $>\chi^{2}=0.00$

To reduce the multidimensionality of our trust variables a factor analysis was done. Based on a principal factor model with varimax rotation we defined three main factors underlying trust, representing generalized trust (factor 1), institutionalized trust (factor 2), and personalized trust (factor 3). Details of the factor analysis are provided in Table 2. Importantly, the endogenous clustering of the data generates variables that are broadly consistent with the theory.

The Kaiser-Meyer-Olkin (KMO) measure of sample adequacy is equal to 0.84 , which indicates the variables are appropriate and share a common value. Based on the factor analysis we thus unbundle households' level of trust into $\mathrm{PT}_{j}$ (level of personalized trust of household $j$ ), $\mathrm{GT}_{j}$ (level of generalized trust of household $j$ ), and $\mathrm{IT}_{j}$ (level of institutionalized trust of household $j$ ). We are interested in the impact of each type of trust on adaptation choices, and therefore include them separately in our model. The different household trust indicators can be formalized as follows:

$\mathrm{HT}_{j}=\alpha_{0} \mathrm{PT}_{j}+\alpha_{1} \mathrm{GT}_{j}+\alpha_{2} \mathrm{IT}_{j}$

where $\alpha_{0}, \alpha_{1}$, and $\alpha_{2}$ are parameters.

Next, we turn to the measurement of adaptation strategies. The literature contains different methods of characterizing livelihood adaptation strategies. Most commonly, data on realized income underlie these classifications, i.e., shares of income earned in different sectors of the rural economy (Dercon and Krishnan 1996). In contrast, we focus on the allocation of assets across distinct activities that reflect the (strategic) choice set of households. Such an asset-based approach is an alternative method for analyzing livelihood adaptation strategies, and demonstrates that the amount of income earned (and even the type of activity undertaken) is a function of the assets controlled by the household (Brown et al. 2006). Following Brown et al. (2006), we formulate asset allocation over livelihood adaptation strategies by assuming that a utility maximizing household allocates its assets over different activities yielding different returns $y$. For each activity $i$ this gives the following income function:

$y_{i}=f_{i}\left(A_{i}\right)+\varepsilon_{i}$

where an income-generating activity, $Y_{\mathrm{i}}$, is assumed to be affected by two elements. The first is an increase in the number and quality of productive assets available $\left(A_{\mathrm{i}}\right)$ and a random component $\left(\varepsilon_{i}\right)$, representing factors beyond the control or expectation of households.

Total household income is defined as $\mathrm{Y}=\sum_{i} \mathrm{y}_{i}$. The allocation options of this income function are constrained by the asset endowment $\mathrm{A}_{0}$ :

$\sum_{i} A_{i} \leq A_{0}$

If the household maximizes its utility of income, then its choice can be defined as:

$\underset{A_{i}}{\operatorname{Max}} U\left(\sum_{i} y_{i}=\Sigma_{i} f_{i}\left(A_{i}\right)+\varepsilon_{i}\right)$

The resulting choice represents the livelihood adaptation strategy. In other words, income composition is considered an outcome rather than a determinant of a livelihood adaptation strategy.

We operationalized the concept of adaptation strategy by quantifying the household's asset portfolio. The clustering of households is based on the use of two primary assets: labor and land. Both household time allocated to different types of productive activities (farm self-employment, farm labor employment, non-farm wage-employment, non-farm self-employment, and unskilled domestic labor) and the household land-use pattern (land allocation to maize production and other crops, mainly pasture) are used to identify categories of household strategies. Table 1 (part 2) shows the summary statistics of the labor and land variables.

We used cluster analysis to 'group' our observations on the land and labor variables into distinct livelihood adaptation strategy types. Cluster analysis summarizes a large number of sample observations by assigning them to a smaller, tractable number of distinct groups-'clusters'of observations. Households with similar time allocation and land-use pattern are grouped together. First, a Ward's linkage hierarchical cluster analysis is used to agglomerate clusters of observation within our data set. Based on statistical results, we identified three distinct strategy clusters 
in the data and use this result as input for the $k$-means cluster analysis to assign each household to a distinct group. $K$-means cluster analysis is a method of partitioning data into a predetermined number of groups (i.e., $\mathrm{k}=3$ ). (Lattin et al. 2003). Observations are initially randomly assigned to one of the $k$ clusters, and then reassigned using an iterative method to minimize within-cluster variance and maximize between-cluster variance.

Finally, we discuss the measurement of wealth. As we do not have complete data on household income or consumption, we used the possession of consumer assets as an indicator of wealth. Following Filmer and Pritchett (2001), we used the Principal Component Analysis (PCA) to compose a Wealth Index which allows us to compare consumer assets endowments across households (e.g., television, bed, radio, bicycle, etc.). In this context the factor 'wealth' is assumed to underlie ownership of all included assets (Clarke 2006, p. 6). To ensure sampling adequacy, the KMO test was used to compare the magnitudes of observed correlation coefficients with the magnitudes of partial correlation coefficients. The KMO measure of sampling adequacy is equal to 0.68 , indicating that the assets share a common factor (Sahn and Stifel 2003).

\section{Model design}

Adaptation strategy choice was hypothesized to depend on a household's trust indicators. We estimate the overall effect of a household's trust as:

$L C_{j}=\beta_{0}+\beta_{1} H T_{j}+\varepsilon_{j}$,

where $\mathrm{LC}_{j}$ refers to the livelihood adaptation choice of household $j, \mathrm{HT}_{j}$ refers to an overall trust indicator for the household, and $\varepsilon_{j}$ is the error term. To control for the potential effects of the household's capital endowments we extended the model:

$L C_{j}=\beta_{0}+\beta_{1} H T_{j}+\beta_{2} C_{A P I T A L S}+\varepsilon_{j}$

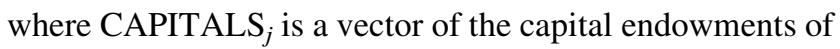
household $j$.

Following the livelihood framework, we assume the livelihood strategy choice is determined by slowly changing exogenous capitals, including households' natural, human, social, physical, and financial capital. Natural capital includes land owned (more land stimulates farm activities) and land entitlements (land titles can be used as collateral and stimulate investments). Human capital variables include household size and dependency ratio (labor availability), sex and age of the household head (femaleheaded households have specific characteristics and face competing demand on the time of the household head), and education level of household head (important for the offfarm employment opportunities). Physical capital refers to urban land entitlements (collateral). By excluding financial and social capital, we minimize potential endogeneity problems. For example, farmer group participation was not used as a proxy for social capital since this is highly correlated with maize production strategy (these groups only provide services to maize farmers). Table 1 (part 3) summarizes these variables.

We integrate Eq. (1) into our model, which results in:

$$
\begin{aligned}
\mathrm{LC}_{j}= & \beta_{0}+\beta_{1} \alpha_{0} \mathrm{PT}_{j}+\beta 1 \alpha_{1} \mathrm{GT}_{j}+\beta_{1} \alpha_{2} \mathrm{IT}_{j} \\
& +\beta_{2} \mathrm{CAPITALS}_{j}+\varepsilon_{j} \\
= & \beta_{0}+\gamma_{0} \mathrm{PT}_{j}+\gamma_{1} \mathrm{GT}_{j}+\gamma_{2} \mathrm{IT}_{j}+\beta_{2} \mathrm{CAPITALS}_{j}+\varepsilon_{j},
\end{aligned}
$$

where $\gamma_{0}, \gamma_{1}, \gamma_{2}$ are the parameters of the trust variables.

We ran a multinomial logistic regression ${ }^{1}$ to analyze the determinants of households' livelihood choice. A multinomial logistic regression predicts the probability that a household will select each of a set of alternative strategies compared to a reference strategy. We use the traditionally dominant strategy of maize farming as the reference activity, and analyze the characteristics of households that have adjusted to new market opportunities created by market liberalization and reverted to an alternative strategy. A positive estimated coefficient indicates an increase in the likelihood that a household chooses the alternative livelihood strategy; a negative coefficient indicates a lower likelihood.

Finally, we link livelihood choices to economic outcomes for which we use an Asset Index. We use the level of the Asset Index (Z) as our proxy for household income-a variable less subject to shocks than annual income. The regression is as follows:

$Z_{j}=\beta_{0}+\beta_{1} S T R 1_{j}+\beta_{2} S T R 2_{j}+\beta_{3}$ CAPITALS $_{j}+\varepsilon_{j}$

where $S T R 1_{j}$ and $S T R 2_{j}$ are dummy variables for pursuing a diversified livelihood strategy and pursuing a cattlebreeding strategy, respectively.

However, the empirical approach outlined above may be too simple. To obtain consistent estimates of the causal effect of an explanatory variable on the dependent variable, the error term of the model must not be correlated with the regressors (that is $E(\varepsilon \mid \mathrm{x})=0$ ). This means that the choice for a certain livelihood strategy should not be determined by (omitted) factors that also influence differences in the level of trust among households. Similarly, before we can interpret the results of a regression model as 'causal' we need to rule out 'reverse causality'. That is: there may be two-way interaction. Trust can impact strategies, but the economic activities emanating from these strategies in turn may affect trust levels as well. In such cases, the (conditional)

\footnotetext{
${ }^{1}$ We use a multinominal logit model because adaptation strategy choice is a polychotomous variable; i.e., it is a categorical variable that has more than two values.
} 
correlation between regressor and dependent variable cannot be interpreted as a causal effect. A common approach to overcome these potential endogeneity problems is to use an instrumental variable (IV) estimator (Dougherty 1992). This instrumental variable, $w$, needs to be correlated with the endogenous variables $\mathrm{x}$, and uncorrelated with the error term (so $E(\varepsilon \mid w)=0$ ). Hence, we are looking for exogenous variables that determine trust levels, and do not affect strategy choice in any way other than via trust levels. Needless to say such instruments are scarce.

We hypothesize that personalized trust may be treated as exogenous variable, built up slowly over one's life in response to extended periods of interaction with relatives and friends. We tried to find a suitable instrumental variable to explore this issue further, but were unsuccessful. This implies the coefficients for personalized trust should be treated as associations only, and not necessarily as causal effects. The same is true for the outcomes of generalized trust.

However, we were able to find an instrumental variable for institutionalized trust. We base our choice on the social and historical context. Past experiences influence current levels of institutionalized trust: people being disadvantaged by official authorities in the past might have low levels of institutional trust today (for example, such trust attitudes may be transmitted via their parents). The recent past is characterized by many internal conflicts concerning access to land. Some farmers were able to keep the land that they were used to cultivating while others did not receive land titles or received parcels far away. We assume low levels of institutionalized trust among this latter category of households:

$I T_{j}=F\left(\right.$ DISTANCE $\left._{j}, T_{T I T L E}\right)$

where DISTANCE ${ }_{j}$ refers to the distance of the parcel of household $j$ (in meters) and $T I T L E_{j}$ refers to the parcel land title of household $j$. In case the household head was younger than 40 years old, we asked about the distance and land title of his/her father instead because they were too young to obtain land in $1985 .^{2}$

\section{Trust and community development in a historical perspective}

Since current levels of trust are shaped by significant political and economic events, we first take a closer look at relevant developments in the recent local history. Indeed, historical variables will also play a role in the empirical analysis that follows.

\footnotetext{
2 This assumption is reliable as the quality of soil is the same everywhere, and based on a pairwise correlation test we can conclude that there is no significant correlation between "distance," "title," and "strategy 1, 2 or 3."
}

The end of the Mexican Revolution: new internal conflicts and social friction

The Mexican Revolution officially ended in 1920, but peace between the various revolutionary bands and guerrilla combatants in the Sierra de Santa Marta did not prevail until 1928 (Kuhfuss 2007). New violent conflicts emerged because of a lack of consensus on the restitution of land among various groups of Popolucas. 'Comunalistas' fought for the restoration of the old situation preceding the revolution. Access to land was common at that time, without boundaries between the different communities in the Sierra. The young 'agraristas', in contrast, preferred the government's proposal to donate each community ejido land, and renounced common access to land to stimulate agricultural development and market integration (Velázquez Hernández 2006). The internal conflicts resulted in the rise of a few political leaders who used the situation to acquire power and authority in a society with low levels of social stratification.

Due to these conflicts, a decision concerning the restitution of land was postponed and, consequently, local smallholders kept their long-established common access to land throughout the 1920s and 1930s. At that time nobody owned land, but usufruct rights were carefully guarded. People cultivated maize and beans at different small plots scattered throughout the lowland zones of the Sierra de Santa Marta, called milpas. Abandoned milpas became part of the public domain (Foster 1943). People also grew other crops and plants in different ecological zones throughout the Sierra (Velázquez Hernández 2001).

Foundation of Morelos: community as social capital

By the end of the 1930s, owing to the internal conflicts about land rights, small groups of young families left their villages to search for political and productive autonomy and established new communities (Léonard and Hernández 2009). The community of Morelos was founded on the site of an old ranch deserted during the revolution in 1937. The municipality of Soteapan required the setup of an agrarian committee (comité agrario) of which the president became the key authority in the village, representing the community in the municipality. In addition, the villagers appointed one of the founders of the community as local judge to mediate interpersonal disputes among villagers.

At the time of origin, about fifteen families lived in this new community. Agriculture was the main livelihood activity and cultivation was primarily for own consumption. Households were self-supportive and enjoyed a large measure of autonomy. There were no shops; men went to neighboring villages to exchange their maize and beans for other products, such as salt, soap, sugar, and lime. Intra- 
household kin relations were the most important social network. Inter-household interactions were mainly confined to the exchange of products. Social life in the community was simple and collective action was rare. Key informants explained that the local authority occasionally convened a community gathering, during which community members discussed what improvements were needed in the village, and what collective action had to be taken. This type of communal work, a service to the community, was called 'tequio', which existed until the 1970s.

Over the years, the availability of land triggered an inflow of new families from neighboring villages. As a result, Morelos became one of the fastest growing communities in the Sierra, causing deforestation and a decline of the local natural resource base in the 1950s (Blanco Rosas 2006). According to key informants, concurrent with the growth of the population, life in the village became more individualistic. Villagers did not trust the newcomers, and new conflicts started to arise about access to land. Despite the increased number of inhabitants, there were no clubs or associations, and people had few contacts with members of neighboring communities, except for trade purposes.

Formation of the ejido: increased social stratification

Despite the disapproval of the local leaders who fought for the restitution of communal land, a group of 147 farmers of Morelos applied for ejido land in 1944 (Blanco Rosas 2006). In 1956, the government granted the donation, and allocated the community with 3,590 ha of land. From that moment onwards, Morelos was officially an ejido-a community-based organization in which members, or ejidatarios, held permanent usufruct rights to one or several plots. Under this system, any form of land transaction was outlawed since the Mexican government owned the ejidos (Bouquet 2009). The newly obtained status of ejido changed the local governance structure by inducing new governance institutions that replaced the agrarian committee: an executive body, an oversight council, and a general assembly.

The implementation of the ejido system affected livelihood activities and local social relations. It forced farmers to cultivate within the borders of the land allocated to the ejido, excluding them from access to areas more adequate for producing coffee, hunting, and fishing situated in other parts of the Sierra de Santa Marta. Moreover, the ejido system caused social stratification between smallholders as only the 147 registered $^{3}$ ejidatarios were allocated with

\footnotetext{
3 According to key informants, a few household heads were not registered because they refused to participate in the national household census due to a lack of confidence in strangers.
}

usufruct land rights. Consequently, unregistered household heads and sons of ejidatarios who just started their own household no longer had access to land. Those without usufruct land rights were called avecindados. Social conflicts arose as the ejido law conflicted with the tradition according to which not only each ejidatario but also each household head-registered or not-had access to land to become food secure. Conflicts about land intensified, and jealous community members attacked others with machetes, robbed each other's harvest, and expropriated community land. According to key informants, at that time, the level of trust among community members was very low and many houses permanently closed their windows with shutters. Family life took place within the domestic domain, and women and children hardly left the compound.

We hypothesize that the difference in rights between ejidatarios and avecindados affects the level of institutionalized trust between both groups of households (i.e., avecindados are likely to have lower levels of institutionalized trust than ejidatarios). We return to this below.

\section{Land allocation and recovery of trust}

Internal conflicts delayed the distribution of land. It was not until 1987 that all land was divided into individual parcels, and allocated to the ejidatarios. An important issue causing tensions among villagers was the location of the parcels. Most preferred parcels were those at a short distance from the village. People ending up with parcels at a large distance felt they were put at a disadvantage. (Hence, in what follows, we use the distance of the parcel as a variable in our empirical model as this might influence the level of trust in local authorities and governmental institutions.) A group of avecindados organized themselves, and in 1985 asked the general assembly of ejidatarios for permission to split up the 590 ha of common grazing land into individual parcels of three hectares each. This was the first time that a grassroots organization was formed to realize a common goal in Morelos. The ejidatarios approved the request and granted 156 avecindados usufruct rights to land.

While the allocation of land has attenuated internal conflicts and increased social cohesion, the level of trust among community members remains remarkably low. Respondents indicate they hardly trust people beyond the household. Representative excerpts from interviews are as follows:

In Morelos you cannot trust many people. People are selfish. To be honest, I only trust my own children. Even my husband cheats me. A few weeks ago I caught him going out with another woman in Acayucan. Maybe it is because of my age that I have 
a low opinion of the trustworthiness of people. Too often I felt a victim of corruption, lies, and fraud. That is why I lost all my credulity. (Alejandra Aleman, 74);

I don't trust any local authority or political leader. They all are bandits. They always guarantee developments and prosperity but they never realize their promises. The same applies to the previous Comisariado Ejidal. Despite being the son of my brother he deceived me by selling me fertilizers for twice the market price. (Roberto Cruz, 42);

I know that if I tell my neighbors something personal or secret, they will tell it to the entire community. They always gossip about other people. Therefore, I always whisper when I talk about personal matters because I am afraid that my neighbors listen. (Claudia Velazquez, 32);

I never lend out money to family or friends because I am not sure they will pay me back. In our community, people often do not follow up on agreements. (Eduardo Mateo, 24).

As described in our theoretical review, we hypothesize that current levels of institutionalized trust are embedded in the past. Based on the local social-historical context of Morelos, we expect lower levels of institutionalized trust among household heads historically excluded from land titles (avecindados) compared to those household heads owing land titles (ejidatarios). Consistent with our expectations, the data in Table 3 show significantly lower levels of institutionalized trust among avecindados. These outcomes suggest that our instrumental variable 'land title' is reasonable. There are no significant differences in personalized and generalized trust between the groups. The low level of trust in both categories is remarkable, and confirms the results of the in-depth interviews in which key informants depicted households as being solitary-minded,

Table 3 Differences in mean trust indicators between ejidatarios and avecindados

\begin{tabular}{llll}
\hline & $\begin{array}{l}\text { Ejidatarios } \\
(\mathrm{n}=45)\end{array}$ & $\begin{array}{l}\text { Avecindados } \\
(\mathrm{n}=155)\end{array}$ & $T$ value \\
\hline Personalized trust & 0.059 & 0.039 & 0.901 \\
Generalized trust & $(0.109)$ & $(0.091)$ & \\
Institutionalized trust & 0.188 & 0.105 & 0.609 \\
& $(0.135)$ & $(0.084)$ & \\
& $(0.463$ & 0.061 & $0.011^{* * *}$ \\
\hline
\end{tabular}

$* p<0.1 ; * * p<0.05 ; * * * p<0.01$

Standard errors in parentheses, $\mathrm{N}=200$ preferring to live their life independently, working individually, and not considering kin, neighbors, friends, and other villagers as a source of support.

\section{Empirical results}

Our cluster analysis identified three main categories of livelihood strategies. Table 4 summarizes the means and standard errors for the variables that were used.

The livelihood strategy of households in cluster 1 is based on diversified income by engaging in activities outside the farm. Households in this cluster spend almost all their land (92\%) and about $40 \%$ of their productive time on agricultural activities. This time is almost completely (93\%) allocated to maize production. The remainder of the time is spent mostly in temporary wage-employment (46\% of productive time) in the farm sector (for instance at pineapple and sugar cane plantations) and non-farm sector. Besides, they spend a small percentage of time (about $13 \%$ ) on non-farm selfemployment. It is remarkable that households in cluster 1 have the lowest percentage of total household time spent on domestic activities; so their dependency ratio is on average lower than that of the households involved in cattle breeding and maize production.

Cluster 2 includes households that use their agricultural land and labor not only for the production of maize, but also for pasture (about $52 \%$ of their land and $26 \%$ of their agricultural labor). In addition to farm self-employment, these households dedicate about $14.5 \%$ of their productive time to non-farm and off-farm activities. This cluster represents $12.5 \%$ of the households in the sample.

Cluster 3 represents the majority of the households (67\%). The most distinguishing feature of households in cluster 3 is that they primarily allocate their household productive time (about $97 \%$ ) and land (99\%) to the production of maize. They do not use on-farm and off-farm alternative income sources to supplement their maize income. Households in this cluster have the highest dependency ratio suggesting that the household is characterized by a higher percentage of women and/or children who do not contribute to the household income compared to households involved in cattle breeding and diversified livelihood activities.

Correlations between trust and livelihood strategy choice

We run a multinomial logistic regression to analyze how personalized, generalized, and institutionalized trust influenced household's livelihood choice. The outcomes of this regression are presented in Table 5 (maize cultivation is treated as the omitted category). 
Table 4 Livelihood strategy categories estimated via K-median cluster analysis

\begin{tabular}{|c|c|c|c|c|c|c|}
\hline & \multicolumn{2}{|c|}{ Cluster 1} & \multicolumn{2}{|c|}{ Cluster 2} & \multicolumn{2}{|c|}{ Cluster 3} \\
\hline & Mean & SE & Mean & SE & Mean & SE \\
\hline \multicolumn{7}{|l|}{ Land allocation ( $\%$ of cultivated land) } \\
\hline Maize & 92.2 & 3.03 & 48.1 & 3.97 & 99.1 & 0.40 \\
\hline Pasture & 7.8 & 3.04 & 51.9 & 3.91 & 0.92 & 0.40 \\
\hline \multicolumn{7}{|l|}{ Labor allocation ( \% of productive time) } \\
\hline Farm self-employment & 39.6 & 2.79 & 83.4 & 3.93 & 97.1 & 0.65 \\
\hline Farm wage employment & 20.9 & 4.01 & 3.6 & 1.69 & 0.71 & 0.34 \\
\hline Non-farm self-employment & 13.3 & 3.66 & 12.9 & 3.45 & 1.50 & 0.50 \\
\hline Non-farm wage employment & 26.2 & 4.72 & 0.1 & 0.00 & 0.65 & 0.32 \\
\hline Domestic time and education ( $\%$ of total household time) & 40.7 & 3.25 & 44.9 & 4.34 & 47.3 & 1.35 \\
\hline \multicolumn{7}{|l|}{ Agricultural time allocation } \\
\hline Agricultural time on maize & 93.4 & 2.97 & 74.0 & 3.56 & 99.1 & 0.44 \\
\hline Agricultural time on other crops/pasture & 6.6 & 1.20 & 26.0 & 2.76 & 0.92 & 0.24 \\
\hline $\mathrm{n}(\%)$ & \multicolumn{2}{|c|}{$40(20 \%)$} & \multicolumn{2}{|c|}{$25(12.5 \%)$} & \multicolumn{2}{|c|}{$135(67.5 \%)$} \\
\hline Name of livelihood strategy & \multicolumn{2}{|c|}{ Diversified smallholder } & \multicolumn{2}{|c|}{ Cattle and pasture farmer } & \multicolumn{2}{|c|}{ Maize farmer } \\
\hline
\end{tabular}

The model outcomes help us to obtain a better understanding of the factors that determine livelihood adaptation choices. Households having more generalized and institutionalized trust are more likely to be involved in the diversified livelihood strategy than in the maize producing strategy. By contrast, high levels of personalized trust are negatively correlated with livelihood diversification but positively associated with the cattle-breeding strategy. This means that people with high levels of personalized trust are more likely to be involved in cattle breeding and pasture growing than in the maize production strategy.

Not surprisingly, the table also demonstrates that other household characteristics are correlated with livelihoods. For example, households owning many hectares are more likely to be engaged in the cattle-breeding strategy than in maize production. Similarly, households entitled with urban land are more likely to invest in cattle breeding than continuing maize production. Households with female household heads appear to be involved in an alternative strategy and are less likely to pursue maize production. Furthermore, household size matters for the livelihood choice: a large household is positively correlated with participating in diversified livelihood strategies. Moreover, high dependency ratios are positively correlated with being involved in maize production. ${ }^{4}$

As mentioned, the analysis potentially suffers from an endogeneity problem. For example, one could argue that people participating in diversified livelihood activities are

\footnotetext{
${ }^{4}$ We have computed the marginal effects for each variable. Institutionalized trust seems to be a relatively important variable that has a significant positive effect on livelihood diversification and a negative effect on maize production (data available on request).
}

more involved in markets, and learn more about the intentions and behavior of others and as such enhance trust (Tu and Bulte 2010) or perhaps there are omitted variables driving both trust and livelihood choice. We therefore run an IV probit model, where we instrument for institutionalized trust (using land entitlement and location of the parcel as excluded instruments in the first stage). The outcomes of this model were only significant in case of strategy choice 1 , the diversification strategy, which is the only result shown in Table 6 .

The results of the 1st stage (column 3) suggest our instruments are able to predict institutionalized trust (i.e., are able to identify exogenous variation in this potentially endogenous variable). Moreover, the (predicted) institutionalized trust still enters significantly and with the correct sign in the 2nd stage of the analysis (column 2) supports the view that there is a positive causal relationship between institutionalized trust and diversified livelihood strategy. Hence, households having more institutional trust are, as a result of that, more likely to be involved in the diversified livelihood strategy.

Trust as a key determinant of livelihoods

We use qualitative data to interpret and complement the outcomes of the survey. Our qualitative data confirm the associations resulting from the multivariate analysis, and support the view that the relations between personalized and generalized trust are not only associations but causal relations (even if we do not have appropriate instrumental variables to formally 'test' these hypotheses). Moreover, the data validate the direction of rationale: trust determines livelihood choices. 
Table 5 Multinomial logistic regression of livelihood strategy choice

\begin{tabular}{|c|c|c|}
\hline Capitals & $\begin{array}{l}\text { Diversified } \\
\text { smallholder } \\
\text { strategy }\end{array}$ & $\begin{array}{l}\text { Cattle and } \\
\text { pasture } \\
\text { farmer } \\
\text { strategy }\end{array}$ \\
\hline Institutionalized trust & $\begin{array}{l}0.839 * * * \\
(0.259)\end{array}$ & $\begin{array}{l}-0.451 \\
(0.324)\end{array}$ \\
\hline Generalized trust & $\begin{array}{l}0.508 * * \\
(0.234)\end{array}$ & $\begin{array}{l}-0.286 \\
(0.321)\end{array}$ \\
\hline Personalized trust & $\begin{array}{l}-0.474^{*} \\
(0.267)\end{array}$ & $\begin{array}{l}0.492 * \\
(0.288)\end{array}$ \\
\hline Sex household head (female $=1$ ) & $\begin{array}{l}2.434 * * * \\
(0.772)\end{array}$ & $\begin{array}{l}1.981 * * \\
(0.874)\end{array}$ \\
\hline Age household head & $\begin{array}{l}-0.024 \\
(0.021)\end{array}$ & $\begin{array}{l}-0.034 \\
(0.028)\end{array}$ \\
\hline Household dependency ratio & $\begin{array}{l}-1.590^{* * *} \\
(0.542)\end{array}$ & $\begin{array}{l}-0.797 \\
(0.784)\end{array}$ \\
\hline Illiterate household head (yes $=1$ ) & $\begin{array}{l}-0.629 \\
(0.493)\end{array}$ & $\begin{array}{l}-0.132 \\
(0.664)\end{array}$ \\
\hline Land owned (ha) & $\begin{array}{l}0.018 \\
(0.042)\end{array}$ & $\begin{array}{l}0.198 * * * \\
(0.045)\end{array}$ \\
\hline Household size & $\begin{array}{l}0.579 * * * \\
(0.156)\end{array}$ & $\begin{array}{l}-0.074 \\
(0.214)\end{array}$ \\
\hline $\begin{array}{l}\text { Solar land (land for settlement) owned } \\
\quad(\text { yes }=1)\end{array}$ & $\begin{array}{l}0.240 \\
(0.597)\end{array}$ & $\begin{array}{l}20.629 * * * \\
(1.565)\end{array}$ \\
\hline Constant & $\begin{array}{l}-2.752 * * * \\
(0.889)\end{array}$ & $\begin{array}{l}-21.594 \\
(.)\end{array}$ \\
\hline
\end{tabular}

$* p<0.1 ; * * p<0.05 ; * * * p<0.01$

Standard errors in parentheses

Pseudo $\mathrm{R}^{2}=0.3676$; $\operatorname{LR} \chi^{2}(20)=124.55$

Strategy $3=$ base outcome

The diversified livelihood strategy includes households that allocate a considerable percentage of their labor to non-farm and off-farm income generating activities. Both push and pull factors stimulate livelihood diversification. Low maize prices and high input costs force smallholders to get involved in additional (non-farm) income generating activities. Moreover, changing market conditions and increasing demand for agricultural labor in other areas of the country have stimulated (temporarily) migration among farmers from Morelos.

Frequently, household members hear about job opportunities from villagers, intermediaries, or suppliers in Acayucan. Therefore, one needs to have an extensive network to get involved in off-farm livelihood activities. For this reason, generalized trust is positively associated with livelihood diversification strategy. The chance to gain additional income makes young men leave their family for a few weeks, months, or sometimes years to work in the construction industry or at plantations. People without strong social ties with kin and community members are
Table 6 Instrumental variable probit

\begin{tabular}{lll}
\hline Diversified smallholder strategy & $\begin{array}{l}\text { Second } \\
\text { stage }\end{array}$ & First stage \\
\hline 2nd stage & $\begin{array}{l}\text { Coefficient } \\
0.899^{* * *}\end{array}$ & \\
Institutionalized trust & $(0.339)$ & \\
Personalized trust & -0.221 & \\
& $(0.157)$ & \\
Generalized trust & 0.357 & \\
& $(0.240)$ & Yes \\
Included 7 control & Yes & \\
$\quad$ variables (CAPITALS) & & $6.33 \mathrm{E}-05^{* * *}$ \\
Distance & & $(3.65 \mathrm{E}-05)$ \\
& & $0.000045^{* * *}$ \\
Land title $(1=$ yes) & & $(3.17 \mathrm{E}-05)$ \\
\hline
\end{tabular}

Standard errors in parentheses

Wald test of exogeneity (/athrho $=0): \chi^{2}(1)=1.18$; Prob $>\chi^{2}=$ 0.2781

more likely to stay away from their household for extended periods of time. Consequently, low levels of personalized trust are associated with people pursuing labor work outside the community. People who leave the village for a long time are not able to continue their maize production or other agricultural activities. This requires a high level of institutionalized trust as they have to give up their source of food security and become completely dependent on the market.

Another common type of non-farm work is starting up your own business. This livelihood activity requires a high level of generalized and institutionalized trust. A good relationship with middlemen and wholesalers may lead to price reductions or deferred payments, which are crucial to remain in business in the first months. Moreover, running a small shop or cantina (small bar) involves generalized and institutionalized trust as you have to negotiate with strangers and become an active player in the market.

Farmers engaged in the cattle-breeding strategy own a few heads of cattle and/or use (part of) their land for pasture instead of maize. Farmers do not have to visit their cattle every day as the cows are not used for dairy production. They lead the cattle out to pasture and occasionally check the physical condition of their livestock. Cattle breeding is often combined with pasture growing which is a laborextensive activity, since pasture needs less fertilizers and pesticides than maize. Consequently, smallholders involved in this strategy are less dependent on hired labor, and interact less with other people. For this reason, trust in strangers (or generalized trust) is not crucial for them.

In contrast, households involved in cattle breeding often work close together with kin. Investments in cattle are high, and frequently family members share the costs. This 
involves agreeing on when to slaughter, sell, or buy livestock. Households often start working together when two or three sons inherit a fraction of their fathers parcel each. They may collectively sell a part of the land and invest the revenues in purchasing heads of cattle. Many times, brothers live at the same compound, stimulating cooperation. Collective investment in cattle requires a high level of trust among kin, which explains the positive association between cattle breeding and personalized trust in the Table 5 .

Traditionally, smallholders produce maize to support themselves. From generation to generation, smallholders transmit the knowledge on how to grow maize. Consequently, households can autonomously cultivate their own produce without any interference of others. For this reason, while high levels of trust in kin is important, trust in people beyond the household or in the institutional environment is not required. This is in line with the independent and solitary norms present in the community.

However, since the introduction of monoculture maize production and the introduction of improved seed varieties at the beginning of the 1990s, smallholders have become more dependent on agrochemicals such as pesticides and fertilizers, the application of which is labor-intensive. To produce greater market surpluses, smallholders use these agrochemicals and hire labor workers for support. While historically reciprocity among kin relations beyond the household and close friends was common, nowadays everybody wants to receive a day wage for their labor. As a result, an increasing number of smallholders hire people beyond the family, and generalized trust becomes more important.

Since the liberalization of the agricultural sector and the withdrawal of government supports to smallholders, the input market has become complex with a wide spectrum of suppliers. The position of the smallholders tends to be weak because of their lack of education and knowledge. As a result one would expect that smallholders will become more dependent on knowledge and information sharing with others, and that in the future personalized and generalized trust will play a more important role in maize production. On the other hand, without an increase in levels of institutionalized trust, smallholders will not easily leave maize production and switch to other better marketable products.

Trust and wealth

Finally, we use an asset index as a proxy for household wealth, and explore whether this index is positively correlated with involvement in the diversified or cattle-breeding strategy. Table 7 shows the results of a simple regression model. We conclude that, conditional on household characteristics, livelihood strategies are not significantly correlated with wealth. That is: different forms of trust appear to affect
Table 7 Correlation between wealth and adaptation strategy choice

\begin{tabular}{ll}
\hline Wealth & Coefficient \\
\hline Diversified smallholder strategy & 0.462 \\
& $(0.354)$ \\
Cattle and pasture farmer strategy & 0.728 \\
& $(0.459)$ \\
Sex household head (female $=1)$ & -0.256 \\
Age household head & $(0.461)$ \\
& -0.017 \\
Household dependency ratio & $(0.012)$ \\
Illiterate household head (yes $=1)$ & -0.387 \\
Land owned (ha.) & $(0.295)$ \\
& -0.294 \\
Household size & $(0.263)$ \\
Solar land (land for settlement) owned (yes $=1)$ & 0.030 \\
Constant & $(0.024)$ \\
& $0.449 * * *$ \\
& $(0.099$ \\
& -0.048 \\
& $(0.330)$ \\
& $-1.498^{* *}$ \\
& $(0.646)$ \\
\hline
\end{tabular}

$* p<0.1 ; * * p<0.05 ; * * * p<0.01$

Standard errors in parentheses

$\mathrm{F}(9,190)=5.68 ;$ Prob $>\mathrm{F}=0.00$

$\mathrm{R}^{2}=0.2120 ;$ Pseudo $\mathrm{R}^{2}=0.1747$

livelihood choices, but in turn these choices are not very consequential for our measure of household wealth (after taking other factors into account that explain wealth). This is consistent with a simple economics choice model where sizable income differences across livelihood strategies are gradually arbitraged away.

\section{Discussion and conclusion}

A growing literature identifies the importance of adaptation strategies for dealing with variability and change in the socio-economic systems in which smallholders live. We argue that social capital—and trust in particular-offers ways into understanding the role of the social and institutional context in such adaptive behavior. We base our conclusions on a qualitative and quantitative analysis of the relationship between trust, livelihood strategy choice, and wealth. In particular, we have investigated the role of personalized, generalized, and institutional trust in adaptation choices of smallholders after recent neoliberal market reforms.

Our most significant result is that households with a high level of generalized and institutionalized trust are more 
likely to invest productive assets (time and land) in alternative livelihood strategies. By contrast, households with high personalized trust are more likely to be engaged in cattle breeding and pasture growing activities.

While such correlations are of interest in themselves, they are even more interesting when we can interpret them as 'causal'. Our data allow us to verify this for one specific form of trust-institutional trust. Our qualitative analysis of the local historical context suggests one plausible instrumental variable that we have used for this purpose.

Our historical analysis suggests that livelihood adaptation is the result of long-standing processes that are intrinsically intertwined with processes of community development and trust building in which contingencies and path-dependency play a significant role. We describe how changing market conditions and macro-economic policy reforms have affected the external vulnerability context of smallholders in Morelos. In the course of three generations, land tenure and the farming system changed from an indigenous slash-and-burn, patchy, common land-use system, into a regulated and registered ejido characterized by individual usufruct land rights, and finally into a community of smallholders with individual land titles. In this process, not all smallholders were treated equally, and not all households have benefitted from new land titles or land reallocations. We used this information to motivate an IV model by assuming that smallholders who received land titles have a higher level of generalized and institutional trust than smallholders who have no access to land. Moreover, the location of the appointed land is used as an instrument since parcels located nearby the community were favored. The outcomes of our IV model make our assumption valid that generalized trust partly determines the adaptation choice of households. However, it is important to emphasize that the coefficient is small, and the role of generalized trust appears relatively modest.

Another result is a positive association between personalized trust and participation in cattle breeding. Unfortunately, we did not find an appropriate instrumental variable to verify a causal effect. However, in-depth interviews with local farmers made clear that before starting cattle-breeding activities households often have a high level of personalized trust. Frequently, smallholders and kin relations invest together in cattle, as this livelihood strategy requires many hectares of land and a large starting capital. This supports the view that personalized trust shapes the livelihood choice.

Overall, lack of generalized and institutionalized trust seems to explain why most smallholders continue producing maize. People who do not trust 'markets' show risk-averse behavior, and prefer to provide for their own food rather than search for other livelihood opportunities. Hence, trust and formal institutions are complements in the sense that greater trust in strangers and institutions results in greater market participation. This is consistent with evidence presented by Tu and Bulte (2010). However, our study also suggests that this choice is not very consequential in terms of asset accumulation. Controlling for a range of household characteristics we find no evidence of a significant correlation between livelihood strategies and wealth (which does not imply that livelihood strategies are inconsequential for revenues, income or income stability, of course).

Open Access This article is distributed under the terms of the Creative Commons Attribution License which permits any use, distribution, and reproduction in any medium, provided the original author(s) and the source are credited.

\section{References}

Ahlerup, P., O. Olsson, and D. Yanagizawa. 2009. Social capital vs institutions in the growth process. European Journal of Political Economy 25(1): 1-14.

Algan, Y., and P. Cahuc. 2006. Why is the minimum wage so high in low-trust countries? Mimeo University of Paris 1.

Algan, Y., and P. Cahuc. 2007. Social attitudes and macroeconomic performance: An epidemiological approach. Мimeo University of Paris 1.

Arrow, K.J. 1972. Gifts and exchanges. Philosophy \& Public Affairs 1: 343-362.

Beugelsdijk, S., H.L.F. De Groot, and A.B.T.M. Schaik. 2004. Trust and economic growth: A robustness analysis. Oxford Economic Papers 56: 118-134.

Blanco Rosas, J.L. 2006. Erosion de la Agrodiversidad en la Milpa de los Zoque Popoluca de Soteapan: Xutuchincon y Aktevet. Mexico D.F.: Universidad Iberoamericana.

Bouquet, E. 2009. State-led land reform and local institutional change: Land titles, land markets and tenure security in Mexican communities. World Development 37(8): 1390-1399.

Brown, Douglas.R., Emma.C. Stephens, James.Okuro. Oumac, Festus.M. Murithid, and Christopher.B. Barrett. 2006. Livelihood strategies in the rural Kenyan highlands. African Journal of Agricultural and Resource Economics 1(1): 21-36.

Buckles, D., and O. Erenstein. 1996. Intensifying maize-based cropping systems in the Sierra de Santa Marta, Veracruz. NRG Paper 96-07. Mexico, DF: CIMMYT.

Bussolo, M., and H.S. Lecomte. 1999. Trade liberalisation and poverty. Poverty Briefing Paper No. 6. London: The Overseas Development Institute.

Calderón, C., C. Alberto, and G. Arturo. 2002. Development efficiency of the financial sector and links with trust: Cross-country evidence. Economic Development and Cultural Change 51(1): 189-204.

Clarke, R. 2006. Measuring wealth across seven Thai communities. WeD Working Paper No. 17. Bath: ESRC Research Group on Wellbeing in Development Countries, University of Bath.

CONEVAL. 2005. Población Total, Pobreza por Ingresos, Indicadores, Indice y Grado de Rezago Social, Según Municipio.

Dasgupta, P. 1998. Trust as a commodity. In Trust: Making and breaking cooperative relations, ed. D. Gambetta, 49-72. Oxford: Basil Blackford.

Davies, S. 1993. Are coping strategies a cop out? IDS Bulletin 24(4): 60-72.

Davies, S., and N. Hossain. 2007. Livelihood adaptation, public action and civil society: A review of the literature. IDS Working Paper No. 57. 
Dercon, S., and P. Krishnan. 1996. A consumption-based measure of poverty in Ethiopia 1989-1994. In Poverty and economic reform in Ethiopia, proceedings annual conference of the Ethiopian Economic Association.

Dohmen, T., A. Falk, D. Huffman, and U. Sunde. 2006. The intergenerational transmission of risk and trust attitudes. IZA Discussion Paper No. 2380. Bonn: Forschungsinstitut zur Zukunft der Arbeit Institute for the Study of Labor.

Dougherty, C. 1992. Introduction to econometrics. New York: Oxford University Press.

Durlauf, S.N., and M. Fafchamps. 2004. Social capital. NBER Working Paper No. W10485. Madison: Department of Economics, National Bureau of Economic Research, University of Wisconsin.

Easterly, W. 2005. The white man's burden. New York: The Penguin Press.

Ellis, F. 2000. Rural livelihood and diversity in developing countries: Analysis, methods, policy. Oxford: Oxford University Press.

Emirbayer, M., and A. Mische. 1994. What is agency? American Journal of Sociology 103(4): 962-1023.

Fafchamps, M. 2002. Social capital, trust, and development. Social development strategy. Washington DC: The World Bank.

Filmer, D., and L.H. Pritchett. 2001. Estimating wealth effects without expenditure data-or tears: An application to educational enrollments in States of India. Demography 38(1): 115-132.

Foster, G.M. 1943. The geographical, linguistic, and cultural position of the Popoluca of Veracruz. American Anthropologist 45(4): 531-546.

Fukuyama, F. 1995. Trust: The social virtues and the creation of prosperity. London: Hamish Hamilton.

Gambetta, D. 1998. Trust: Making and breaking cooperative relations. Oxford: Basil Blackwell.

Garfinkel, H. 1963. A conception of, and experiments with "Trust" as a condition of stable concerted actions. In Motivation and social interaction: Cognitive determinants, ed. O.J. Harvey, 187-238. New York: The Ronald Press.

Grootaert, C., and T. Van Bastelaer. 2002. Understanding and measuring social capital: A multidisciplinary tool for practitioners. Washington, DC: The World Bank.

Guiso, L., P. Sapienza, and L. Zingales. 2006. Does culture affect economic outcomes? Journal of Economic Perspectives 20: 23-48.

Hughes, P., J. Bellamy, and A. Black. 2000. Breaking social trust trough education. In Social capital and public policy in Australia, ed. L. Winter, 225-249. Melbourne: Australian Institute of Family Studies.

INEGI. 2005. Dirección General de Estadística, Direccción General Adjunta de Estadísticas Sociodemográficas; Direccíon de Análisis y Estudios Demográficos.

Knack, S. 2000. Trust, associational life and economic performance. In Paper presented at HRDC-OECD international symposium on the contribution of investment in human and social capital to sustained economic growth and wellbeing. Washington, DC: The World Bank.

Knack, S., and P. Keefer. 1997. Does social capital have an economic pay-off? Quarterly Journal of Economics. 112(4): 1251-1288.

Kramer, R.M. 1999. Trust and distrust in organizations: Emerging perspectives, enduring questions. Annual Review in Psychology 50: 569-598.

Kuhfuss, L. 2007. Enchâssement Social des Arrangements Contractuels dans la Céréaliculture Marchande en Zone Indienne: Etude de Cas à Morelos, Etat de Veracruz, Mexique. Master Thesis. Montpellier: Université Montpellier.

La Porta, R., F. Lopez-de-Silanes, A. Schleifer, and R.W. Vishny. 1997. Trust in large organisations. American Economic Review 87: $333-338$
Lattin, J., J.D. Carroll, and P.E. Green. 2003. Analyzing multivariate data. Toronto: Thomson Brooks/Cole.

Léonard, E., and E. Velázquez Hernández. 2009. El Reparto Agrario y el Fraccionamiento de los Territorios Comunitarios en el Sotavento Veracruzano: Construcción Local del Estado e Impugnación del Proyecto Comunal. In El Istmo Mexicano: Una Región Inasequible. Estado, Poderes Locales y Dinámicas Espaciales (Siglos XVI-XXI), eds. E. Velázquez Hernández, E. Léonard, O. Hoffmann, and M.-F. Prévôt-Schapira, 399-454. México, DF: Publicaciones de la Casa Chata.

Murray, C. 2001. Livelihood research: some conceptual and methodological issues. CPRC Background Paper 5.

Pelling, M., and C. High. 2005. Understanding adaptation: What can social capital offer assessments of adaptive capacity? Global Environmental Change Part A 15(4): 308-319. doi:10.1016/j. gloenvcha.2005.02.001.

Pennartz, P., and A. Niehof. 1999. The domestic domain: Changes, choices and strategies of family households. Aldershot: Ashgate Publishing Limited.

Platteau, J.P. 1994. Behind the market stage where real societies exist: Part I-the role of public and private order institutions. Journal of Development Studies 30(3): 533-577.

Portes, A. 1998. Social capital: Its origin and applications in modern sociology. Annual Review of Sociology 24: 1-24.

Putnam, R.D. 1995. Bowling alone: America's declining social capital. Journal of Democracy 6(1): 65-78.

Putnam, R.D. 1998. Foreword. Housing Policy Debate 9(1): V-viii.

Sabatini, F. 2009. Does social capital create trust? Evidence from a community of entrepreneurs. Fondazione Eni Enrico Mattei Working Paper No. 305. Siena: University of Siena.

Sahn, D., and D. Stifel. 2003. Exploring alternative measures of welfare in the absent of expenditure data. Review of Income and Wealth 49(4): 463-489.

Smit, B., and J. Wandel. 2006. Adaptation, adaptive capacity and vulnerability. Global Environmental Change 16(3): 282-292.

Stone, W. 2001. Measuring social capital: towards a theoretically informed measurement framework for researching social capital in family and community life. Research Paper No. 24. Melbourne: Australian Institute of Family Studies.

Tabillini, G. 2007. Institutions and culture. CEPR Discussion Paper No. 330. Milano: Universita Bocconi.

Tu, Q., and E. Bulte. 2010. Trust, market participation and economic outcomes: Evidence from Rural China. World Development 38(8): 1179-1190.

Uphoff, N. 2000. Understanding social capital: Learning from the analysis and experience of participation. In Social capital: A multifaceted perspective, ed. P. Dasgupta, and I. Serageldin. Washington, DC: The World Bank.

Uslaner, E.M. 1999. Trust and consequences. Paper Presented to the Communitarian Summit, February 1999, Arlington, VA.

Uslaner, E.M. 2002. The moral foundations of trust. Cambridge: Cambridge University Press.

Velázquez Hernández, E. 2001. El Territorio de los Popolucas de Soteapan, Veracruz: Transformaciones en la Organización y Apropiación del Espacio. Relaciones 87(22): 17-47.

Velázquez Hernández, E. 2006. Territorios Fragmentados: Estado y Comunidad Indigena en el Istmo Veracruzano. México, DF: Publicaciones de la Casa Chata.

Whiteley, P.F. 2000. Economic growth and social capital. Political Studies 48(2000): 443-466.

Wise, T.A. 2007. Policy space for mexican maize: Protecting agrobiodiversity by promoting rural livelihoods. Working Paper No. 07-01. Medford MA: Tufts University.

Zak, P.J., and S. Knack. 2001. Trust and growth. Economic Journal 111: 295-321. 
Zoomers, E.B. 1999. Livelihood strategies and development: Experiences from the Bolivian Andes. Amsterdam: Royal Tropical Institute.

\section{Author Biographies}

Sytske F. Groenewald PhD, wrote her doctoral thesis for the Wageningen University in The Netherlands. Her study focuses on livelihood strategies of small-scale maize producers in Veracruz
(Mexico) under NAFTA and emphasizes the significant role of social capital in their adaptation process. She holds a degree in Cultural Anthropology (MA) and International Economics (BA) from Utrecht University, The Netherlands.

Erwin Bulte PhD, is professor of economics at Wageningen University and Tilburg University. He is also a research fellow at the University of Cambridge, UK, and an advisor to the UN Food and Agriculture Organization. His research interests lie at the interface of natural resources, economic growth and development, and institutional change. 